\title{
The role of green rust in the environment: A review ${ }^{1}$
}

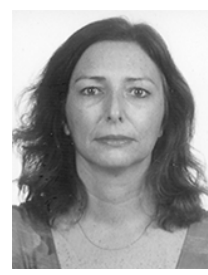

Lucia H. G. Chaves²

\begin{abstract}
${ }^{1}$ Part of the Postdoctoral research conducted at University of Arizona with the support of the CAPES
2 DEAg/UFCG, CP 10087,CEP 58109-970, Campina Grande, PB. Fone: (83) 3310-1285. E-mail: Ihgarofalo@hotmail.com
\end{abstract}

Protocolo 31 - 6/2/2004 - Aprovado em 14/1/2005

\begin{abstract}
Iron(II)-iron(III) hydroxy-salts known as green rusts (GRs) initially were identified and studied as corrosion products of steel and iron. Recently they were discovered as minerals present in hydromorphic soils and sediments. Different studies have suggested that GRs, due to their high reactivity, play an important role in the fate and transport of many contaminants in suboxic soils, sediments and aquifers where microbial reduction rates are limited by low carbon content. Also, GRs have considerable potential for applications such as water-purification processes and gas adsorbents. However, as GRs are only a transient state during the reduction of ferric iron and are converted to more stable forms, it is still necessary to continue studies about their behavior.
\end{abstract}

Key words: $\mathrm{Fe}(\mathrm{II}) \mathrm{Fe}(\mathrm{III})$-hydroxides, abiotic transformations, remediation.

\section{O papel do green rust no ambiente}

\begin{abstract}
Resumo: Hidróxidos de ferro (II)-ferro(III) conhecidos como "green rust" (GR), inicialmente foram identificados e estudados como sendo os produtos provenientes da corrosão do aço e do ferro. Recentemente esses hidróxidos foram encontrados na forma mineral em solos hidromórficos e em sedimentos. Devido a sua alta reatividade, muitos trabalhos têm mostrado que esses hidróxidos desempenham um importante papel no destino e transporte de muitos contaminantes em solos subóxicos, sedimentos e aqüíferos, onde a taxa de redução microbiana é limitada pelo baixo conteúdo de carbono. Os "green rusts" também podem ser utilizados nos processos de purificação de águas e como adsorventes de gases. Entretanto, como GR são considerados uma fase transitória durante a redução do íon férrico e são, rapidamente, convertidos para formas mais estáveis, é necessário que os estudos sobre seu comportamento continuem.
\end{abstract}

Palavras-chave: Fe(II)Fe(III)-hydróxidos, transformações abióticas, remediação

\section{INTRODUCTION}

Green rusts (GRs) are unstable compounds containing a mixture of ferrous and ferric iron and are known as green rusts (GRs) due to their bluish green colors. Structurally, green rust (GR) belongs to a family of minerals known as layered double hydroxides (LDH) synthesized for the first time by Girard \& Chaudron (1935), cited by Trolard et al. (1997). The discovery of these compounds in natural environments was connected to corrosion of steel in the soil environment. green rust was first described by Keller (1948) cited by Cuttler et al. (1990), who produced a chloride and sulphate GRs. Initially green rusts had been identified and studied as corrosion products of steel and iron water distribution pipes and are now recognized as an important intermediate phase in the corrosion of $\mathrm{Fe}(0)$ (Stampfl, 1969). They were also identified as products of pitting corrosion processes of stainless steels (Boucherit et al., 1991; Bigham \& Tuovinen, 1985). Recent research has identified green rust II as corrosion product for carbon steel exposed to the atmosphere (Rodríguez et al., 2002).

A study by Bernal et al. (1959) of iron oxyhydroxides, which included green rusts, identified two forms of the sulphate species as well as the chloride form. These GRs were prepared "by the oxidation of ferrous iron solutions" but the method was not described in sufficient detail to enable repeatition of these studies.

Green rusts are formed by a number of abiotic and biotic processes under circumneutral to alkaline conditions in suboxic environments. They have been identified as products of both abiotic and microbially induced corrosion of iron and steel 
(Bigham \& Tuovinen, 1985; Refait et al., 1998). In addition, the formation of green rust by bacteria known to be key players in the biogeochemical cycling of Fe has recently been reported. Various strains of the dissimilatory iron reducing bacterium Shewanella putrefaciens produce green rusts as products of bioreduction of hydrous ferric oxide and lepidocrocite (Fredrickson et al., 1998; Parmar et al., 2001; Glasauer et al., 2002; Genin, 2003). Recent investigations in the laboratory have proved that a GR was the resulting product of reduction of lepidocrocite by this bacterium (Ona-Nguema et al., 2002). Moreover, GRs are also observed as products of the anaerobic biooxidation of Fe(II) by Dechlorosoma suillum (Chaudhuri et al., 2001). Refait et al. (2003), recently studying the mechanisms leading to $\mathrm{GR}$ - $\mathrm{SO}_{4}$ in marine corrosion of steel, reported that the presence of this mineral in the outer part of the rust layer on the steel could be explained by microbially influenced corrosion from dissimilatory iron reducing bacteria in anaerobic conditions. Erbs (2003) investigating the biotic formation of GR in two different anoxic bath systems using a dissimilatory iron(III)-reducing microorganism coupling oxidation of organic matter with iron(III)reduction (Shewanella algae BrY) and autotrophic iron(II) oxidizers coupling oxidation of iron(II) with nitrate reduction, found that the nitrifying $\mathrm{Fe}(\mathrm{II})$-oxidizing bacteria produce a green intermediate solid phase within 3 days after inoculation.

Based on the bluish green color often encountered in wet soils and sediments and the rapidity with which this color changes on exposure to oxygen, Taylor \& McKenzie (1980) argued that green rust might form in natural environments. From studies of the oxidation products of synthetic green rust, Taylor (1980) and Hansen (1989) suggested that the green rusts might be important precursors for different iron oxides in soils, depending on environmental conditions. However, the presence of green rust in a natural environment needed to be demonstrated to substantiate its importance. But, the rapid reaction of green rusts with atmospheric oxygen made it difficult to identify these compounds in natural and engineered systems (Williams \& Scherer, 2001). Usually, oxidation of green rusts results in the formation of ferrihydrite $\left(\mathrm{Fe}_{5} \mathrm{HO}_{8} \cdot 4 \mathrm{H}_{2} \mathrm{O}\right)$, goethite (á-FeOOH), akaganeite (â-FeOOH), lepidocrocite (ã-FeOOH), hematite (á- $\left.\mathrm{Fe}_{2} \mathrm{O}_{3}\right)$ maghemite $\left(\tilde{a}-\mathrm{Fe}_{2} \mathrm{O}_{3}\right)$ or magnetite $\left(\mathrm{Fe}_{3} \mathrm{O}_{4}\right)$, depending on $\mathrm{pH}$, solution composition, oxidant, rate of oxidation, and the degree and rate of dehydration (LoyauxLawniczak et al., 2000; Lin et al., 1996). Green rusts are believed to play a central role in the redox cycling of $\mathrm{Fe}$ in aquatic and terrestrial environments.

More recently, however, direct evidence for the presence of green rusts in hydromorphic soils under forest in Fougères, Brittany, France, has been tentatively identified as hydroxygreen rust $\left(\mathrm{GR}_{\mathrm{OH}}\right)$ and given the proposed name fougerite (Trolard et al., 1996 cited for Génin et al., 2001; Trolard et al., 1997). In accordance with Bourrié et al. (1999), the solubility of Fe in hydromorphic soil solution is controlled by equilibrium with $\mathrm{GR}_{\mathrm{OH}}$. But conclusive evidences for the formation of GRs in soils and sediments is still waiting (Hansen, 2003).

\section{COMPOSITION, STRUCTURE AND SYNTHESIS OF GREEN RUST}

Green rusts are layered Fe(II)-Fe(III) hydroxides having a pyroaurite-type structure consisting of alternating positively charged hydroxide layers and hydrated anion layers. Some of the $\mathrm{Fe}(\mathrm{II})$ of the octahedral sheets of $\mathrm{Fe}(\mathrm{OH})_{2}$ is replaced by $\mathrm{Fe}(\mathrm{III})$. This results in a positive layer charge that is balanced by the inclusion of anions between the layers (Bernal et al., 1959). Its exact nature depends on the interlayer anion, and various forms have been synthesized and studied. However the results of many studies have shown that GRs obey to a specific chemical composition, a stoichiometry, and can be represented with the general formula:

$$
\left[\mathrm{Fe}_{(6-\mathrm{x})}^{\mathrm{II}} \mathrm{Fe}_{\mathrm{x}}^{\mathrm{III}}(\mathrm{OH})_{12}\right]^{\mathrm{x}+}\left[(\mathrm{A})_{\mathrm{x} / \mathrm{n}} \cdot \mathrm{yH}_{2} \mathrm{O}\right]^{\mathrm{x}-}
$$

where $\mathrm{x}=0.9-4.2$, $\mathrm{A}$ is an n-valent anion (typically $\mathrm{CO}_{3}{ }^{2-}$, $\mathrm{Cl}^{-}$or $\mathrm{SO}_{4}^{2-}$ and y denotes the varying amounts of interlayer water (typically y $=2$ to 4 for most GRs).

The literature distinguishes between $\mathrm{GRI}\left(\mathrm{A}^{\mathrm{n}-}=\mathrm{F}^{-}, \mathrm{Cl}^{-}, \mathrm{Br}\right.$, $\left.\mathrm{I}^{-}\right)$, GRII $\left(\mathrm{A}^{\mathrm{n}-}=\mathrm{SO}_{4}{ }^{2-}\right)$ and GR- $\mathrm{CO}_{3}\left(\mathrm{~A}^{\mathrm{n}-}=\mathrm{CO}_{3}{ }^{2-}\right)$. This division is due to a crystallographic classification of the mineral structures by which GRI is described as rhombic obtained with "planar" anions such as chlorides, carbonate etc, while GRII and GR$\mathrm{CO}_{3}$ are hexagonal obtained with three-dimensional tetrahedral anions such as sulphate or selenate (Legrand et al., 2001). Green rusts, unlike most iron oxides and whatever their form, have an internal surface area so these minerals have great specific surface areas and consequently great reactivity. But, most of the work reported to date has focused on the reactivity of sulfate green rust rather than the chloride or carbonate forms of green rust (Williams \& Scherer, 2001). They represent reactive ion exchangers and sorbents (Hansen et al., 2001). The amphoteric surface hydroxyl groups lead to both sorption of heavy metals (cations) as well as organic anions, e.g. linear alkyl benzene sulfonates (LAS), the major synthetic surfactant used in laundry detergents and cleaning products worldwide, and inorganic anions, e.g. silicate, arsenate and selenate. Furthermore, polar non-charged compounds are sorbed into the interlayer. In addition, cations as $\mathrm{Cu}(\mathrm{II}), \mathrm{Ni}(\mathrm{II}), \mathrm{Zn}(\mathrm{II}), \mathrm{Cd}(\mathrm{II})$, $\mathrm{Co}(\mathrm{II})$ and $\mathrm{Mg}(\mathrm{II})$, may isomorphically substitute for $\mathrm{Fe}(\mathrm{II})$ during green rusts formation (coprecipitation). For instance, nickelous-ferric green rusts, the end products obtained by substitution of $\mathrm{Fe}(\mathrm{II})$ ions by $\mathrm{Ni}(\mathrm{II})$ ions in green rust, have been demonstrated by Refait \& Génin $(1993,1997)$ and Refait et al. (1994, 1998). This incorporation of cationic inorganic contaminants into the structures of green rusts could provide an effective means of sequestering contaminants in the subsurface.

Various processes have been developed to synthesize GRs in the laboratory. Two main procedures were envisioned, the first one by partial oxidation of $\mathrm{Fe}(\mathrm{II})$ hydroxides or $\mathrm{Fe}(\mathrm{II})$ solutions, the second one by mixing $\mathrm{Fe}(\mathrm{II})$ and $\mathrm{Fe}(\mathrm{III})$ aqueous solutions or suspensions (coprecipitation). The anion associated with $\mathrm{Fe}(\mathrm{II})$ or $\mathrm{Fe}(\mathrm{II})$ and $\mathrm{Fe}(\mathrm{III})$ in the salt is thus 
present in solution and induces the formation of the corresponding GR, e.g. using $\mathrm{FeSO}_{4}$ leads to GR-SO . Géhin et al. (2002) have reported that the composition of GR-SO prepared by coprecipitation is the same as that observed for GR-SO ${ }_{4}$ samples prepared by other methods. A recent article by Legrand et al. (2001) was devoted to new carbonate green rust obtained by electrochemical way, in other words, by other way.

\section{GREEN RUST AS REDUCTANT}

Abiotic transformations (oxidations/reductions) of inorganic and organic substances are generally much slower than biotic reactions, but they have proved significant within the time scales commonly associated with groundwater movement. Groundwater and hydromorphic soils constitute environments with low microbial activity in which the abiotic transformation of organic and inorganic contaminants can be important in the presence of highly reactive GR. Abiotic reduction of different anions in the presence of synthetic GRs has been reported, for example, the reduction of nitrite $\left(\mathrm{NO}_{2}^{-}\right)$ and nitrate $\left(\mathrm{NO}_{3}^{-}\right)$to ammonium $\left(\mathrm{NH}_{4}^{+}\right)$by GR-SO $\mathrm{S}_{4}$. This reduction is a thermodynamically favorable reaction, which may be expected to occur in natural anoxic waters (Hansen et al., 1994; Hansen et al., 1996).

Considerable interest has been given to reduction of $\mathrm{NO}_{3}$, which is widely known as an agricultural pollutant (Sposito, 1989), as it protects groundwater from excessively high $\mathrm{NO}_{3}^{-}$ concentration and contributes for the maintenance of the nitrogen in the ground (Verdegem \& Baert, 1985). The green rust-facilitated $\mathrm{NH}_{4}^{+}$formation may therefore be an important pathway for nitrate removal and $\mathrm{N}$ conservation in anoxic, sulfatic or carbonatic subsoils and sediments poor in organic carbon. The process may explain the disappearance of nitrate from water entering anoxic, Fe(II)-rich layers in sediments where relatively high amounts of exchangeable $\mathrm{NH}_{4}^{+}$can be observed immediately above the redox boundary (Hansen, et al., 1996).

Other example is chromium (Cr), which is more related to specific sites contaminated with industrial wastes. As the use of $\mathrm{Cr}$ is spread over various industrial processes such as metallurgy, electroplating or tanning of leather, it has become a common contaminant found in many soils, waste sites, ground and surface waters throughout the world (Richard \& Bourg, 1991; Puls et al., 1994). Loyaux-Lawniczak et al. (2000) studying the transformation of hexavalent chromium, $\operatorname{Cr}(\mathrm{VI})$, a byproduct of many industrial processes, known to be toxic, carcinogenic and soluble, in the presence of GR-SO $\mathrm{S}_{4}$ and GR-Cl, observed that both the GRs proved to be very reactive and led to the rapid and complete reduction of $\mathrm{Cr}(\mathrm{VI})$ into $\mathrm{Cr}(\mathrm{III})$, a very low solubility product and relatively immobile in the environment. Other experiment, evaluating the capacity of $\mathrm{GR}-\mathrm{CO}_{3}$ for reducing $\mathrm{Cr}(\mathrm{VI})$ into $\mathrm{Cr}(\mathrm{III})$, have showed that $\mathrm{Cr}(\mathrm{VI})$ was not conserved in the system and was reduced to $\mathrm{Cr}(\mathrm{III})$. But, the adsorption or exchange of the $\mathrm{Cr}(\mathrm{VI})$ has most likely occurred before reduction (Williams \& Scherer, 2001).

In the same way, studies have demonstrated that the higher valent and more soluble selenium forms, $\mathrm{Se}(\mathrm{VI})$ reduce to the less reactive $\mathrm{Se}(\mathrm{IV})$ and $\mathrm{Se}(0)$ forms in the presence of GR.
These redox reactions represent an abiotic pathway for selenium cycling in natural environments and can be occurring in the interlayers and on the external surface of GR (Myneni, et al., 1997). Refait et al. (2000) have reported that selenate ions can easily be trapped inside the interlayers of $\mathrm{Fe}(\mathrm{II})-\mathrm{Fe}(\mathrm{III})$ hydroxysalts favoring the formation of hydroxy selenate, a new GR-SeO compound, which can reduce Se(VI) to less mobile Se(IV) forms. As Se compounds are carcinogenic and teratogenic at high concentration, it is important to understand the interactions of $\mathrm{SeO}_{4}{ }^{2-}$ anions with GRs through the formation and transformation of the corresponding GR-SeO ${ }_{4}$, and the concomitant reduction of Se(VI) into Se(IV).

More recently, O'Loughlin et al. (2003), reported that hexavalent uranium, U(VI) (as soluble uranyl ion and with potentially high mobility in the subsurface), was readily reduced by GR-SO $\mathrm{S}_{4}$ to $\mathrm{U}(\mathrm{IV})$ in the form of relatively insoluble $\mathrm{UO}_{2}$ nanoparticles, suggesting that the presence of GR in the subsurface may have significant effects on the mobility of uranium, particularly under iron-reducing conditions.

In the same way, GR might presumably reduce sorbed arsenate to the more toxic and mobile As(III) species. However, Randall et al. (2001), found that $\mathrm{As}(\mathrm{V})$ is not reduced to the $\mathrm{As}(\mathrm{III})$ form and that it remains adsorbed as $\left(\mathrm{AsO}_{4}\right)^{3-}$ by forming inner-sphere surface complexes. During the oxidation of GR to lepidocrocite, the $\left(\mathrm{AsO}_{4}\right)^{3-}$ remains preferentially bound to GR and only sorbed onto lepidocrocite when all of the GR has been oxidized.

Since the oxidation state of polyvalent elements such as N, $\mathrm{Se}, \mathrm{Cr}$ or $\mathrm{U}$ determine their mobility and toxicity in the environment, their interaction with reactive mineral such as GRs could be a clue to the comprehension and control of their behavior (Sposito, 1989). The possible reduction of these elements may be part of a natural process, but it could also be of major importance in soils contaminated with them (Génin et al., 2001). However, the researchers still do not know whether the GR transformed or dissolved the polyvalent elements trapped inside them could be removed, could be reduced to soluble or insoluble forms, could be rendered more mobile or could be definitively fixed (Refait et al., 2000).

In addition, earlier work has shown that carbon tetrachloride is transformed by abiotic reductive dechlorination with synthetic GR-SO as reductant (Erbs et al., 1999). Carbon tetrachloride belongs to a group of halogenated aliphatics, which are released from industrial, commercial and agricultural sources, and they are both highly toxic and carcinogenic as well as prevalent soil and groundwater contaminants. Hence, knowledge of their transformation potential and the products formed are crucial in evaluating their environmental fate. So, GR may be useful for the remediation of chlorinated hydrocarbon contamination in the subsurface.

According to Hansen et al. (1994, 1996) and Roh et al. (2000), the exploitation of GRs to water treatments and in situ remediation of polluted soils and sediments seems possible. In that case, GRs could be applied to transform inorganic and heavily degradable and toxic organic contaminants. Furthermore, it is likely that these reactive iron hydroxides can replace zero-valent iron as a reductant, as they probably have a better penetrating ability in soils and sediments. Remediating 
contaminated groundwater with zero-valent metals has been used widely by several researchers.

\section{CONCLUSIONS}

1. The results of different studies suggest that green rusts play an important role in the fate and transport of many contaminants in suboxic soils, sediments and aquifers where microbial reduction rates are limited by low carbon content.

2. Green rusts have considerable potential in applications such as water-purification processes, gas adsorbents, catalysis and design of drug and pesticide delivery systems.

3. Green rust is only a transient state during the reduction of ferric iron and it is converted to more stable forms, due to this the researchers still do not have answers for many questions, thus, it is still necessary to continue studies about its behavior.

\section{LITERATURE CITED}

Bernal, J.D.; Dasgupta, D.R.; Mackay, A.L. The oxides and hydroxides of iron and their strucutural inter-relationships. Clay Minerals Bulletin, London, v.4, n.21, p. 15-30, 1959.

Bigham, J.M.; Tuovinen, O.H. Mineralogical, morphological and microbiological characteristics of tubercles in cast iron water mains as related to their chemical activity. In: Caldwell, D.E.; Brierley, J.A.; Brierley, C.L. (eds).: Planetary Ecology, New York : van Nostrand Reinhold, 1985, p. 239-250.

Boucherit, N.; Hugot-Le Goff, A.; Joiret, S. Raman studies of corrosion films grown on $\mathrm{Fe}$ and Fe-6Mo in pitting conditions. Corrosion Science, Leeds, v.32, n.5-6, p.497-507, 1991.

Bourrié; G.; Trolard, F.; Génin, J.M.R.; Jaffrezic, A.; Maître, V.; Abdelmoula, M. Iron control by equilibria between hydroxygreen rusts and solutions in hydromorphic soils. Geochimica et Cosmochimica Acta., St. Louis, v.63, n.19-20, p.3417-3427, 1999.

Chaudhuri, S.K.; Lack, J.G.; Coates, J.D. Biogenic magnetite formation through anaerobic biooxidation of Fe(II). Applied Environmental Microbiology, v.67, n.6, p. 2844-2848, 2001.

Cuttler, A.H.; Man, V.; Cranshaw, T.E.; Longworth, G. A Mössbauer study of green rust precipitates: I. Preparations from sulphate solutions. Clay Minerals, London, v.25, n.3, p.289-301, 1990.

Erbs, M. Biogenic formation of mixed valent iron hydroxides (green rust) in the subsurface. In: International Workshop on Biochemical Processes Involving Iron Minerals in Natural Waters, Monte Verità, 2003. Proceedings... 2003. p.24.

Erbs, M.; Hansen, H.C.B.; Olsen, C.E. Reductive dechlorination of carbon tetrachloride using iron(II) iron(III) hydroxide sulfate. Environmental Science Technology, Chapel Hill, v.33, n.2, p.307-311, 1999.

Fredrickson, J.K.; Zachara, J.M.; Kennedy, D.W.; Dong, H.; Onstott, T.C.; Hinman, N.W.; Li, S. Biogenic iron mineralization accompanying the dissimilatory reduction of hydrous ferric oxide by a groundwater bacterium. Geochimica et Cosmochimica Acta., St. Louis, v.62, n. 19-20, p.3239-3257, 1998.
Géhin, A.; Ruby, C.; Addelmoula, M.; Benali, O.; Ghanbaja, J.; Refait, P.; Génin, J.M.R. Synthesis of Fe(II-III) hydroxysulphate green rust by coprecipitation. Solid State Sciences, Paris, v.4, n.1, p.61-66, 2002.

Génin, J.M.R. The mechanisms of genesis of Fe(II-III) hydroxysalt green rusts versus magnetite in the massbalance and E-pH diagrams: coprecipitation, oxidation of $\mathrm{Fe}(\mathrm{OH})_{2}$ and bioreduction. In: International Workshop on Biochemical Processes Involving Iron Minerals in Natural Waters, Monte Verità, 2003. Proceedings... 2003. p.32.

Génin, J.M.R.; Refait, P.; Bourrié, G.; Addelmoula, M.; Trolard, F. Structure and stability of the $\mathrm{Fe}(\mathrm{II})-\mathrm{Fe}(\mathrm{III})$ green rust "fougerite" mineral and its potential for reducing pollutants in soil solutions. Applied Geochemistry, Oxford, v.16, n.5, p.559-570, 2001.

Glasauer, S.; Langley, S.; Beveridge, T.J. Intracellular iron minerals in a dissimilatory iron-reducing bacterium. Journal of Science, v.295, n.5552, p.117-119, 2002.

Hansen, H.C.B. Composition, stabilization, and light absorption of $\mathrm{Fe}$ (II) $\mathrm{Fe}(\mathrm{III})$ hydroxy-carbonate ('Green rust'). Clay Minerals, London, v.24, n.4, p.663-669, 1989.

Hansen, H.C.B. Formation, stability and reactivity of mixedvalent iron(hydr)oxides (green rusts). In: Biochemical Processes Involving Iron Minerals in Natural Waters. Monte Verità, 2003. Proceedings... 2003. p.38.

Hansen, H.C.B.; Borggaard, O.K.; Sorensen, J. Evaluation of the free energy of formation of $\mathrm{Fe}(\mathrm{II})-\mathrm{Fe}(\mathrm{III})$ hydroxide-sulphate (green rust) and its reduction of nitrite. Geochimica et Cosmochimica Acta., St. Louis, v.58, n.12, p.2599-2608, 1994.

Hansen, H.C.B.; Guldberg, S.; Erbs, M.; Koch, C.B. Kinetics of nitrate reduction by green rusts - effects of interlayer anion and $\mathrm{Fe}(\mathrm{II})$ :Fe(III) ratio. Applied Clay Science, v.18, n.1-2, p.81-91, 2001.

Hansen, H.C.B.; Koch, C.B.; Krogh, H.N.; Borggaard, O.K.; Sorensen, J. Abiotic nitrate reduction to ammonium: Key role of green rust. Environmental Science Technology, Washington, D.C., v.30, n.6, p.2053-2056, 1996.

Legrand, L.; Sagon, G.; Lecomte, S.; Chausse, A.; Messina, R. A Raman and infrared study of a new carbonate green rust obtained by electrochemical way. Corrosion Science, Leeds, v.43, n.9, p.1739-1749, 2001.

Lin, R.; Spicer, R.L.; Tungate, F.L.; Davis, B.H. A study of the oxidation of ferrous hydroxide in slightly basic solution to produce $\gamma$-FeOOH. Colloids and Surfaces A: Physicochemical and Engineering Aspects, v.113, n, 1-2, p. 79-96, 1996.

Loyaux-Lawniczak, S.; Refait, Ph; Ehrhardt, J.J.; Lecomte,P.; Génin, J.M.R. Trapping of $\mathrm{Cr}$ by formation of ferrihydrite during the reduction of chromate ions by $\mathrm{Fe}(\mathrm{II})-\mathrm{Fe}(\mathrm{III})$ hydroxysalt green rust. Environmental Science Technology, Washington, D.C., v.34, n.3, p.438-443, 2000.

Myneni, S.C.B.; Tokunaga, T.K.; Brown Jr., G.E. Abiotic selenium redox transformations in the presence of Fe(II,III) oxides. Science, v.278, p.1106-1109, 1997.

O’Loughlin, E.J.; Kelly, S.D.; Cook, R.E.; Csencsits, R.; Kemner, K.M. Reduction of uranium (VI) by mixed iron (II)/ iron(III) hydroxide (green rust): Formation of UO2 nanoparticles. Environmental Science Technology, Washington, D.C., v.37, n.4, p.721-727, 2003. 
Ona-Nguema, G.; Addelmoula, M.; Jorand, F.; Benali, O.; Géhin, A.; Block, J.C.; Génin, J.M.R. Iron(II,III) hydroxycarbonate green rust formation and stabilization from lepidocrocite bioreduction. Environmental Science Technology, Washington, D.C., v.36, n.1, p.16-20, 2002.

Parmar, N.; Gorby, Y.A.; Beveridge, T.J.; Ferris, F.G. Formation of green rust and immobilization of nickel in response to bacterial reduction of hydrous ferric oxide. Geomicrobiology Journal, Ithaca, v.18, n.4, p.375-385, 2001.

Puls, R.W.; Clark, D.A.; Paul, C.J.; Vardy, J. Transport and transformation of hexavalent chromium through soils and into ground water. Journal of Soil Contamination, Amherst, v.3, n.2, p.203-224, 1994.

Randall, S.R.; Sherman, D.M.; Ragnarsdottir, V.K. Sorption of $\mathrm{As}(\mathrm{V})$ on green rust $\left(\mathrm{Fe}_{4}(\mathrm{II}) \mathrm{Fe}_{2}(\mathrm{III})(\mathrm{OH}) 12 \mathrm{SO}_{4} \cdot 3 \mathrm{H}_{2} \mathrm{O}\right)$ and lepidocrocite $(-\mathrm{FeOOH})$ : Surface complexes from EXAFS spectroscopy. Geochimica et Cosmochimica Acta., St. Louis, v.65, n.7, p.1015-1023, 2001.

Refait, Ph.; Abdelmoula, M.; Génin, J.M.R. Oxidation of pyroaurite-like Ni-Fe hydroxychlorides studied by Mössbauer spectroscopy at $16 \mathrm{~K}$. Clay Minerals, London, v.33, n.4, p.665-669, 1998.

Refait, Ph.; Drissi, H.; Génin, J.M.R. The substitution of $\mathrm{Fe}^{2+}$ ions by $\mathrm{Ni}^{2+}$ ions in green rust one compounds. Hyperfine Interactions, Basel, v.90, n.1-4, p.389-394, 1994.

Refait, Ph.; Géhin, A.; Abdelmoula, M.; Génin, J.M.R. Coprecipitation thermodynamics of iron (II-III) hydroxysulphate green rust from $\mathrm{Fe}(\mathrm{II})$ and $\mathrm{Fe}(\mathrm{III})$ salts. Corrosion Science, Leeds, v.45, n.4, p.659-676, 2003.

Refait, Ph.; Génin, J.M.R. The oxidation of Ni(II)-Fe(II) hydroxides in chloride - containing aqueous media. Corrosion Science, Leeds, v.4, n.12, p.2059-2070, 1993.

Refait, Ph.; Génin, J.M.R. Mechanisms of oxidation of Ni(II)$\mathrm{Fe}(\mathrm{II})$ hydroxides in chloride - containing aqueous media: Role of the pyroaurite-type Ni-Fe hydroxychlorides. Clay Minerals, London, v.32, n.4, p.597-613, 1997.

Refait, Ph.; Simon, L.; Génin, J.M.R. Reduction of $\mathrm{SeO}_{4}{ }^{2-}$ anions and anoxic formation of iron(II)-iron(III) hydroxy-selenate green rust. Environmental Science Technology, Washington, D.C., v.34, n.5, p.819-825, 2000.
Richard, F.C.; Bourg, A.C.M. Aqueous geochemistry of chromium: A review. Water. Research, New York, v.25, n.7, p.807-816, 1991.

Rodríguez, J.J.S.; Hernández, F.J.S.; González, J.E.G.XRD and SEM studies of the layer of corrosion products for carbon steel in various different environments in the province of Las Palmas (The Canary Islands, Spain). Corrosion Science, Leeds, v.44, n.11, p.2425-2438, 2002.

Roh, Y.; Lee, S.Y.; Elless, M.P.; Foss, J.E. Incorporation of radioactive contaminants into pyroaurite-like phases by electrochemical synthesis. Clays and Clay Minerals, Aberdeen, v. 48, n.2, p. 266-271, 2000.

Sposito, G. The chemistry of soils. New York: Oxford University Press, 1989, 277p.

Stampfl, P.P. Ein basisches Eisen-II-III- Karbonat in rost. Corrosion Science, Leeds, v. 9, n.3, p. 185-187, 1969. Short Communication

Taylor, R.M. Formation and properties of Fe(II) Fe(III) hydroxycarbonate and its possible significance in soil formation. Clay Minerals, London, v.15, n.4, p.369-382, 1980.

Taylor, R.M.; Mckenzie, R.M. The influence of aluminium on iron oxides. The fomation of $\mathrm{Fe}(\mathrm{II})-\mathrm{Al}(\mathrm{III})$ hydroxy-chlorides, -sulfates and -carbonates as new members of the pyroaurite group and their significance in soils. Clays Clay Minerals, Aberdeen, v.28, n.3, p.179-187, 1980.

Trolard, F.; Génin, J.M.R.; Abdelmoula, M.; Bourrié, G.; Humbert, B.; Herbillon, A. Identification of a green rust mineral in a reductomorphic soil by Mössbauer and Raman spectroscopies. Geochimica et Cosmochimica Acta., St. Louis, v.61, n.5, p.1107-1111, 1997.

Verdegem, L.; Baert, L. Losses of nitrate nitrogen in sandy and clayey soils.2. A qualitative and quantitative approach to the chemical $\mathrm{NO}_{3}{ }^{-} \mathrm{N}$ reduction in reduced subsoils. Pedologie, Ghent, v.35, n.1, p.39-54, 1985.

Williams, A.G.B.; Scherer, M.M. Kinetics of Cr(VI) reduction by carbonate green rust. Environmental Science Technology, Washington, D.C., v.35, n.17, p.3488-3494, 2001. 